\title{
Symbolic Politics or Effective Burden-Sharing? Redistribution, Side-payments and the European Refugee Fund
}

\author{
EIKO R. THIELEMANN \\ London School of Economics and Political Science
}

\begin{abstract}
Explicitly redistributive EU policy instruments are rare. This article seeks to account for the recent establishment of the European refugee fund (ERF), and assess its effectiveness in 'promoting a balance of efforts in receiving and bearing the consequences of displaced persons'. It argues that the decision to create the ERF can be interpreted as an act of partly solidaristic, but mostly symbolic, EU politics. The ERF's redistributive rules are characterized by a side-payment logic in which countries that possess the greatest potential (or most credible threat) to cause difficulties in other areas of EU policymaking are most influential when it comes to the distribution of EU spoils. While this logic can facilitate moves towards further integration, it undermines the achievement of the EU's redistributive objectives.
\end{abstract}

\section{Introduction}

Refugees today constitute one of the most significant migrant groups in the European Union. ${ }^{1}$ As their numbers increased significantly in the 1980s and 1990s, responsibilities for refugees within and across countries became very unevenly distributed. Growth in numbers and their unequal distribution have had a negative impact on the willingness of states (and regions) to provide protection to refugees and have led to two important types of policy response.

\footnotetext{
${ }^{1}$ The term 'refugee' is used here in its broadest sense to characterize individuals who have left their country in the belief that they cannot or should not return to it in the near future, although they might hope to do so if conditions permit. In this usage, the category includes those recognized under the Geneva Convention, but also those who have applied for refugee (or a subsidiary) protection status.
} 
On the one hand, there have been attempts to shift responsibility towards other territories. On the other hand, one has seen the rise of responsibility- (or burden-) sharing initiatives, both within states (through dispersal schemes), and between states (in particular the Member States of the European Union). As far as international burden-sharing is concerned, the establishment of the European refugee fund (ERF) in 2000 (and its recent extension for the 2005-10 period), has arguably been one of the most ground-breaking institutional developments. The ERF, aims 'to promote a 'balance of efforts' in receiving and bearing the consequences of displaced persons' in order 'to demonstrate solidarity between the Member States' in their efforts to promote the social and economic integration of displaced persons. ${ }^{2}$ The ERF does so by allocating common European funds to projects that help with the reception, integration and repatriation of asylum-seekers, refugees and displaced persons at the national, regional and local level. With its aim of promoting a 'balance of efforts' between the Member States, the ERF constitutes one of the very few international institutions that explicitly have redistributive objectives. Explicitly redistributive policy instruments, which are characterized by a 'zero sum' logic ('your gains are my losses'), are generally more contested and more difficult to achieve than regulatory policies that can claim to have 'positive sum' ('everybody gains') characteristics. This has been true in national policy-making, but even more so for attempts to co-operate on such issues in the international arena (Milner, 1992; Young, 1989; Axelrod, 1984; Putnam and Bayne, 1987).

In the context of the European integration process, redistributive instruments have been adopted only very rarely, usually in the context of complex package deals (Wallace, 1977, 1983; Pollack, 1995; Laffan, 2000; Thielemann, 2002). The promotion of new European burden-sharing initiatives in a highly politicized policy area at a time when Member States have been highly sensitive about their net contribution to the EU budget is therefore particularly surprising. The main aim of the article is therefore to analyse the motivation(s) behind these recent European refugee burden-sharing initiatives and their effects. More specifically, it seeks to account for the establishment of the ERF and to assess its effectiveness in promoting burden-sharing and enhancing the protection of refugees. The analysis of the ERF's distributional rules and operational performance, based on recent European Commission evaluation reports (DG Justice and Home Affairs, 2003; Commission, 2004) highlights the fund's achievements as well as some its limitations as a burdenor responsibility-sharing instrument. It will be argued that, despite the talk of solidarity surrounding the creation of this new EU burden-sharing instrument,

${ }^{2}$ Council Decision of 28 September 2000 (2000/596/EC), L252/12 of 6.10.2000. 
the establishment of the ERF has been informed by a similar side-payment logic that has underpinned redistributive politics in other EU policy areas. It will be shown that, while this logic can be expected to have facilitated moves towards a common EU asylum policy, it has limited the fund's redistributive impact and hence its effectiveness as a burden-sharing instrument.

To support this argument, the article will start with a brief overview of the principal theoretical attempts to account for the creation of redistributive agreements beyond the state. This will be followed by an analysis of the distribution of refugee protection burdens and an examination of recent policy responses, with a focus on the establishment and operation of the ERF. The final part of the article seeks to assess the ERF's role and effectiveness within the EU's emerging asylum regime.

\section{Why Share Burdens? Motivations for Redistributive Politics}

How do redistributive bargains come about? While it is unsurprising that likely beneficiaries agree to receive financial transfers, it is less clear why the likely contributors would participate in such apparent 'zero-sum' redistributive schemes. When looking at the creation of past redistributive instruments in the EU, the most prominent explanations for the emergence of redistributive regimes are linked to the ideas of side-payments/package deals, the 'veil of ignorance' and the notion of solidarity. Each of those will be discussed in turn.

A first potential motivation for net contributors can be found in the insurance rationale. There is a large literature which argues that redistributive instruments (such as income tax systems) can be interpreted as an insurance device (Domar and Musgrave, 1944; Buchanon and Tullock, 1962). In such systems, individuals who suffer from a negative income shock enjoy an implicit insurance. In a situation of complete ignorance about their future income, individuals will therefore agree on a certain amount of redistribution even though this redistribution will, from an ex post perspective in which the veil of ignorance has been lifted, be regretted by those who did better than the average (Rawls, 1971). On the basis of an insurance rationale, it might make sense for states to accept a role as net contributor today, if they can expect to become net beneficiaries of the system when in need at some point in the future. In other words, initial net contributors 'might be attracted to burden-sharing for the same reason that many individuals are attracted to catastrophic health insurance' (Schuck, 1997, p. 249).

Second, net contributions might also be made out of a sense of solidarity, equity or fairness. Solidarity can be understood as a concern for other members of a group, which may be expressed by an unwillingness to receive a benefit unless the others do, or an unwillingness to receive a benefit when this will harm 
others. This commitment to the well-being of others is sometimes conceived in terms of the recognition of special obligations between the members of a group, which exist by virtue of their being members of it. Solidarity therefore can be said to exist among a group of actors when they are committed to abide by the outcome of some process of collective decision-making, or to promote the well-being of other members of the group, potentially even when it involved costs to themselves (Mason 2000).

Finally, the incentives for net contributors to take part in a particular fiscal transfer scheme might also be linked to their attempt to facilitate the achievement of other goals that can be linked to such schemes. This is the case when the particular scheme is part of a wider package deal in which contributions are balanced by benefits received through other parts of the overall deal in some quid pro quo fashion. The different contributions made to the package can be seen as evidence of specialization according to the participants comparative advantage, with the overall deal enhancing the collective welfare of all. ${ }^{3}$ Beyond the immediate quid pro quo rationale, net contributors might also be motivated by their desire to achieve other goals, using transfers as side-payments. Side-payments can be understood as offers of compensation - either through financial payments or material concessions on other issues - in an attempt to encourage concessions on a given issue (Friman, 1993, p. 388). In the context of European integration, Carrubba argues that financial transfers thus can provide 'an avenue through which those countries desiring further integration can make side-payments to those opposed to it' (Carrubba, 1997, p. 470), i.e. he shows that transfers are being provided to overcome short-run political constraints on integration (p. 489). ${ }^{4}$

Before trying to establish the extent to which these three logics have played a role in the establishment of the ERF, the article will look first at the distribution of refugee 'burdens' across OECD countries.

\footnotetext{
${ }^{3}$ For example, the early steps in establishing the European Community have often been seen as a package deal between France and Germany, in which Germany agreed to be the major contributor to the common agricultural policy (in which France had a strong interest), in return for which France would agree to the common market (from which Germany as Europe's largest exporting country would disproportionately benefit). Other prominent EU package deals have been observed with, for example, the Delors II budget or Agenda 2000 (Shackleton, 1993; Laffan, 2000).

${ }^{4}$ The basis for this argument is the fact that states have differing preferences over the optimal rate of integration. The more integrationist Member State governments have an incentive to use financial inducements to persuade the less integrationist Member States not to stand in the way of further integration. This in turn provides the potential veto players with opportunities of issue linkage. This has been seen to occur when the passage of the Single European Act was tied to a promised enlargement of the structural funds and also when the passage of the Maastricht Treaty was tied to the creation of the cohesion funds (Moravcsik, 1991; Marks, 1993; Pollack, 1995).
} 


\section{How (In)equitable is the Distribution of Refugee Burdens?}

When comparing their relative contributions to refugee protection, states are likely to disagree about how such contributions should be assessed. By looking at some of the most directly linked burdens/responsibilities that countries are faced with as a result of international refugee flows, it is possible to arrive at some approximations of relative responsibilities that countries are faced with or prepared to accept. Table 1 presents UNHCR data on asylum and resettlement figures for 15 OECD countries (columns 1 and 2) for the period 1994-2002. Columns 4 and 5 list countries' relative burdens on the basis of asylum applications received and resettlement cases accepted (controlling for different population size of host countries). Switzerland, the Netherlands and Belgium have had the largest relative numbers of asylum applications over that period, while Japan, Spain and Italy had the lowest. States have a substantial degree of discretion in how they deal with asylum-seekers in their territory. When dealing with asylum-seekers, countries generally have three options: firstly, recognizing their asylum claims, i.e. granting them refugee status under the Geneva Convention; secondly, giving them some other protection status (such as 'exceptional leave to remain') that allows them to live and (usually) work legally in the country; and, thirdly, rejecting an asylum claim and send the applicant back to their home country. ${ }^{5}$ Column 6 in the table shows a substantial degree of variation in states' willingness to award asylum-seekers in their territory some form of temporary or permanent status (convention or subsidiary protection status). On average, the Netherlands, Denmark and Canada have been the most generous host countries, while Japan, Germany and Australia were the toughest countries when handling requests for protection.

It is of course much easier for a country with small relative asylum inflows to operate a generous determination process than it is for a country faced with large inflows. Indeed previous studies have shown an inverse relationship between asylum application and the recognition rates reported here (Neumayer, 2005).

\footnotetext{
${ }^{5}$ The question of who actually gets recognized as a refugee is still a real issue among the EU Member States. The premise is often that an applicant will have the same chance of finding protection as a refugee in all EU countries. But this is not the case. In the Slovak Republic, for example, many of the asylum-seekers are Chechens - a group that, for good reason, has a recognition rate of well over 50 per cent in several EU countries - yet by 30 September only two people had been granted asylum in the Slovak Republic out of 1,081 cases examined this year. In Greece, even when Saddam Hussein was still in power, fewer than 1 per cent of Iraqi applicants were given refugee status, and the overall recognition rate fell last year to 0.6 per cent. It is not surprising that many asylum-seekers move to countries where they think they have a better chance of having their claims recognized (Lubbers, 2004). In a recent speech Lubbers stressed: 'We need to improve the quality and consistency in asylum decision-making in Europe. It seems unacceptable to me that the same asylum-seeker - a Chechen for example - has virtually zero chance of finding protection in one Member State, a 50 per cent chance in another and close to 100 per cent in a third' (UN High Commissioner for Refugees, Ruud Lubbers, 'Talking Points for the Informal Justice and Home Affairs Council', Luxembourg, 29 January 2005).
} 
Table 1: Average Accepted Protection Burden (1994-2002)

\begin{tabular}{|c|c|c|c|c|c|c|c|c|}
\hline Country & $\begin{array}{c}\text { Av. Ann. No. } \\
\text { of Asylum } \\
\text { Applications }\end{array}$ & $\begin{array}{c}\text { Average } \\
\text { Resettlement } \\
\text { Arrivals }\end{array}$ & $\begin{array}{c}3 \\
\text { Av. Pop. } \\
\text { Size } \\
\text { ('000s) }\end{array}$ & $\begin{array}{c}4 \\
(1) /(3) * 1000 \\
\text { Av. No. of } \\
\text { Asylum App. } \\
\text { (per } 1000 \\
\text { of Pop.) }\end{array}$ & $\begin{array}{c}5 \\
\text { Av. No. of } \\
\text { Resettlement } \\
\text { Arrivals } \\
\text { (per } 1000 \\
\text { of Pop.) }\end{array}$ & $\begin{array}{c}6 \\
\text { Av. } \\
\text { Recognition } \\
\text { Rate } \\
(\%)\end{array}$ & $\begin{array}{c}7 \\
(4)^{*}(6) \\
\text { Av. Accepted } \\
\text { Protection } \\
\text { Burden } \\
\text { (Spontaneous } \\
\text { Arrivals) }\end{array}$ & $\begin{array}{c}8 \\
(5)+(7) \\
\text { Av. Accepted } \\
\text { Protection } \\
\text { Burden } \\
\text { (Spontaneous } \\
\text { Arrivals and } \\
\text { Resettlement) }\end{array}$ \\
\hline Netherlands & 35,345 & 308 & 15,735 & 2.2 & 0.020 & 62.7 & 1.379 & 1.399 \\
\hline Switzerland & 25,208 & 0 & 7,131 & 3.5 & 0.000 & 39.3 & 1.376 & 1.376 \\
\hline Denmark & 8,312 & 1,034 & 5,297 & 1.6 & 0.195 & 61.6 & 0.986 & 1.181 \\
\hline Sweden & 15,556 & 1,945 & 8,855 & 1.8 & 0.220 & 45.1 & 0.812 & 1.031 \\
\hline Norway & 7,836 & 1,494 & 4,435 & 1.8 & 0.337 & 35 & 0.630 & 0.967 \\
\hline Canada & 29,755 & 10,898 & 30,214 & 1 & 0.361 & 59.8 & 0.598 & 0.959 \\
\hline Belgium & 21,532 & 0 & 10,212 & 2.1 & 0.000 & 32.3 & 0.678 & 0.678 \\
\hline Australia & 9,086 & 10,222 & 18,740 & 0.5 & 0.545 & 18.1 & 0.091 & 0.636 \\
\hline United States & 75,484 & 76,243 & 272,181 & 0.3 & 0.280 & 29.7 & 0.089 & 0.369 \\
\hline UK & 61,077 & 39 & 590,40 & 1 & 0.001 & 36.1 & 0.361 & 0.362 \\
\hline Germany & $1,00,844$ & 0 & 820,02 & 1.2 & 0.000 & 15.7 & 0.188 & 0.188 \\
\hline France & 30,595 & 0 & 58,481 & 0.5 & 0.000 & 18.4 & 0.092 & 0.092 \\
\hline Italy & 9,223 & 0 & 57,029 & 0.2 & 0.000 & 24.6 & 0.049 & 0.049 \\
\hline Spain & 7,352 & 0 & 39,669 & 0.2 & 0.000 & 24 & 0.048 & 0.048 \\
\hline Japan & 187 & 162 & 126,383 & 0 & 0.001 & 13.5 & 0.000 & 0.001 \\
\hline
\end{tabular}

Sources: Governments, UNHCR. Compiled by UNHCR (Population Data Unit) (see also «http://www.unhcr.ch» (Statistics); UNHCR Statistical Yearbooks. Notes: * Figures generally refer to the number of persons who applied for asylum. The figures used here are generally first instance ('new') applications only. ** Total recognition rates in industrialized countries (first instance). Includes persons recognized (under Geneva Convention) and those 'allowed to remain' (on the basis of subsidiary protection) divided by the total of recognized, allowed to remain and rejected. 
Column 7 provides an approximation of host countries' willingness to accept burdens resulting from 'spontaneous' refugees (i.e. non-resettlement refugees) by combining the relative number of asylum applications they have received with countries' average recognition rates. The results reported in column 7 suggest that (relative to their population size), the Netherlands, Switzerland and Denmark are on the top of the list of countries which have disproportionately contributed to refugee protection by accepting displaced persons in their territory, while Japan, Italy and Spain appear to have contributed least in this way. Some countries with relatively small numbers of 'spontaneous' asylum applications take in considerable numbers of resettled refugees under a system whereby refugees with a particularly urgent or intractable problem in their first asylum country are transported to a third country. ${ }^{6}$ Taking account of both 'spontaneous' and resettlement inflows, Column 8 presents a ranking of average accepted protection burdens. When comparing the rankings in column 7 (spontaneous only) and column 8 (including resettlement), one sees that the inclusion of resettlement figures does make some difference in the relative ranking of some countries such as Norway, Canada and Australia without, however, changing the overall picture significantly. While the rankings arrived here can be criticized on a number of grounds, not least the comparability of figures that national authorities report to the UNHCR, they do arguably give a burden approximation (with countries such as Netherlands and Switzerland at the top and Japan at the bottom) which appears to be broadly in line with the intuition of experts in the field.

Unequal protection burdens and resulting concentrations of refugees often mean significant pressures on social services and can lead to resentment among the affected host population. ${ }^{7}$ As such they can constitute a serious threat to effective refugee protection. ${ }^{8}$ Concern about disproportionate burdens has led to both unilateral and multi-lateral policy responses that will be discussed next.

\footnotetext{
${ }^{6}$ It has often been emphasized that the traditional 'countries of immigration' (Australia, Canada, New Zealand and the United States) offered resettlement places for up to 100,000 refugees in 2004, whereas Europe as a whole made only 4,700 places available (Ruud Lubbers, 'Talking Points for the Informal Justice and Home Affairs Council', Luxembourg, 29 January 2005).

${ }^{7}$ Resentment among those affected is often felt particularly strongly when the concentration of refugees in perceived as unfair (i.e. not due to particular policy preferences but related to structural pull factors which are beyond the control of policy-makers) and even more so when there is a perception that other states/regions are not pulling their weight in providing protection or are believed to pursue measures that lead to even higher burdens to one's own state/region, i.e. if other actors are seen as pursuing burden-shifting strategies.

${ }^{8}$ This could be witnessed in the UK during the 1990s when around 90 per cent of asylum-seekers were housed in London and the south east (Boswell, 2003). When refugee flows to the UK started to rise significantly from the late 1990s onwards, increasing the pressure on already scarce accommodation in London and the south east of England, the UK government introduced a dispersal scheme for asylum-seekers as part of the 1999 Immigration and Asylum Act. Under this scheme, asylum-seekers are dispersed to 'cluster areas' outside London and the south east, in which there is a sufficient supply of suitable accommodation.
} 


\section{Policy Responses: From Burden-Shifting to Burden-Sharing}

In the light of what countries have perceived as an inequitable distribution of refugee burdens, some states first of all initiated unilateral policy responses, embarking on an international competition to make national legislation more restrictive (relative to those of any neighbouring countries). National policy-making over the past 10-15 years in Europe has been characterized by the adoption of various legislative and administrative instruments aimed to control absolute and relative numbers of asylum-seekers. Policy-makers have introduced changes in three areas in particular in their attempt to raise the deterrence effect of their countries' policy regimes and to lower their countries' relative attractiveness for asylum-seekers. First, measures in the area of access control policy (that relate to rules and procedures governing the admission of foreign nationals) have included the tightening of visa policies, regulations for carriers, safe third-country provisions, etc. Second, rules concerning determination procedures have also been made more restrictive. These have included the operation of countries' refugee recognition systems, rights of appeal, and rules concerning subsidiary protection. Finally, integration policy has been tightened in the process of toughening up countries' asylum regimes. This has meant that rules concerning the rights and benefits given to asylumseekers inside a country of destination (e.g. work and housing conditions, rules on freedom of movement, welfare provisions, educational opportunities, etc.) have also been made more restrictive. ${ }^{9}$ Increasingly, however, there have also been multilateral attempts to co-ordinate national asylum legislation and develop burden-sharing initiatives at the European level (Thielemann, 2003) in an attempt to eliminate policy differences between Member States, and by doing so prevent a potential race to the bottom in protection standards. Since the early 1990s, sparked by the crisis in former Yugoslavia, the EU has developed ambitions for a more 'equitable balance of efforts' in this area. These ambitions for a more comprehensive EU burden-sharing system in this area were made most explicit in the text of the Amsterdam Treaty of October 1997, Article 63 (ex $73 \mathrm{k}$ ) which states that the Council shall adopt measures 'promoting a balance of effort between Member States in receiving and bearing the consequences of refugees and displaced persons'. As a result of such pledges, there have been numerous European burden-sharing initiatives in this area. Following Noll 's (2000) categorization, there are essentially three ways to address the unequal distribution of protection seekers that states are faced with: firstly, harmonizing asylum legislation (sharing policy), secondly, physical burden-sharing (sharing people); and, thirdly, financial burden-sharing (sharing money). In the following

${ }^{9}$ For an overview of changes introduced at the domestic level across European states, see, e.g., Bloch $e t$ al. (2000). 
the first two will be outlined briefly, with the emphasis of the analysis here being placed on the institutionally most advanced burden-sharing initiative in this area, that of financial responsibility sharing through the ERF.

A first possible approach to achieve a more equitable distribution of burdens in this area is to take a common policy approach through either multilateral action or the harmonizing of domestic refugee laws. In this context, the EU has worked towards the convergence of Member States' laws on forced migration since the mid-1980s. What started with initially non-binding intergovernmental instruments has since been followed by developments in Community law. Important stepping stones were the 1995 resolution on minimum guarantees for asylum procedures (Council resolution of 20 June 1995, OJ C 274), the 1999 Amsterdam Treaty establishing a common European asylum system (for an overview, see Guild and Harlow, 2001), the 2002 political agreement at the Brussels JHA Council regarding a common definition for persons eligible for refugee and subsidiary protection status, the 2003 directive on common reception conditions (OJ L/2003/31/18), the September 2003 directive on family reunification (OJ L 251 of 03 October 2003), the Dublin II regulation on the state responsible for examining an asylum application (L50/1 of 25 February 2003) and the commitments made in the November 2004 Hague programme (COM(2005)184 final).

A second set of burden-sharing initiatives has concerned the idea of "peoplesharing', i.e. the redistribution of protection seekers from one host territory to another on the basis of some measure of reception capacity. The first explicit references to physical burden-sharing ambitions were made by EU ministers responsible for asylum and immigration at their meeting of 30 November and 1 December 1992 (not published in the Official Journal, but reprinted in UNHCR, 1995). These deliberations led to a German presidency draft Council resolution on burden-sharing in July 1994 (Council document 7773/94 ASIM 124) which, however, did not find the necessary support in the Council. Other more recent EU initiatives based on the idea of people-sharing have been influenced not only by the recent experience with the refugee crises in Bosnia and Kosovo, but also by people-sharing arrangements found in the refugee regimes of several Member States (Boswell, 2003). Particularly noteworthy in this context is the 2001 Council directive on temporary protection in the case of mass influx (Council directive 2001/55/EC of 20 July 2001,OJ L 212,7 August 2001). Given the limitations of policy harmonization and physical burden-sharing as refugee burden-sharing instruments (Thielemann, 2004, 2005), EU Member States put much of their legislative efforts into a third option for burden-sharing in this area, namely financial burden-sharing. 


\section{The ERF: Origin, Operation and Development}

The ERF can be viewed as the most ambitious attempt to institutionalize refugee burden-sharing in the EU. The fund owes its origin to the Council meeting of justice and home affairs ministers in Tampere in October 1999, ${ }^{10}$ which called for the establishment of a financial reserve for the implementation of emergency measures to provide temporary protection in the event of a mass influx of protection-seekers (European Council, 2000). The resulting Council decision of 28 September 2000 established the European refugee fund (ERF)(OJ L 252/12 of 6 October 2000). According to the Commission, 'The establishment of the European Refugee Fund is the first step towards a common asylum system. ${ }^{11}$... It introduced a system of financial redistribution to balance the burdens borne by the Member States' ${ }^{12}$ Created on the basis of Article 63(2)(b) of the Treaty establishing the European Community, the ERF is to allocate resources proportionately to the burden on each Member State ${ }^{13}$ by reason of their efforts in receiving refugees and displaced persons. This fund, which is jointly financed by the Member States, seeks to support special projects for the reception, integration and repatriation of refugees and displaced persons. ${ }^{14}$ Its rationale is 'to demonstrate solidarity between Member States by achieving a balance in the efforts made by those Member States'. The decision's text also explicitly states that 'it is fair to allocate [EU] resources proportionately to the burden on each Member State by reason of its efforts in receiving refugees and displaced persons'. ${ }^{15}$

\footnotetext{
${ }^{10}$ Pilot projects aimed at refugees and displaced persons have been financed by the Commission since 1997 (Joint Action 97/477/JHA of 22 July 1997). This experience prompted the Union to set up a European Refugee Fund (ERF) grouping in a single instrument the measures relating to integration, reception and voluntary repatriation which had been the subject of the joint action of 26 April 1999 (Joint Action 99/290/JHA).

${ }^{11}$ According to the Commission, this system should include a clear and workable determination of the state responsible for the examination of an asylum application, common standards for a fair and efficient asylum procedure, common minimum conditions of reception of asylum-seekers, and the approximation of rules on the recognition and content of refugee status. It should also include measures on subsidiary forms of protection offering an appropriate status to any person in need of such protection (Commission, 2004, p. 6).

12 «http://www.europa.eu.int/scadplus/leg/en/lvb/133078.htm».

${ }^{13}$ Denmark was the only one of the 'old' EU-15 that did not participate in the ERF, having opted out of common policies on justice and home affairs.

${ }^{14}$ Measures financed by the ERF are for persons with the status of refugee or persons benefiting from another form of international protection and displaced persons benefiting from temporary protection and, depending on the nature of the measures, persons applying for such status or protection. The ERF will support Member States in the following respects: firstly, improvement of reception conditions and procedures in terms of infrastructure and services (accommodation, material assistance, medical care, social assistance, assistance with administrative and judicial formalities); secondly, integration of persons benefiting from a stable form of international protection (aid for immediate needs, socio-cultural adjustment); and, thirdly, voluntary repatriation and reintegration in the country of origin. Community assistance will give access to reliable information, necessary advice, training and assistance for reintegration.
}

${ }^{15}$ OJ L 252/12 of 6 October 2000 (para. 11). 
Despite its rather modest budget, in financial terms it is the largest EU programme on asylum and immigration. For the period 2000-04 (when its first funding cycle came to an end), the ERF aimed to disburse a total of $€ 216$ million over this time according to two elements, one fixed and one proportional. ${ }^{16}$ With regard to the fixed element, a minimum amount is allocated to each Member State each year (this amount was reduced gradually from $€ 500,000$ annually in 2000 to $€ 100,000$ in 2004). The remainder of the resources is divided between the Member States on the basis of statistics compiled by the European Communities Statistical Office on the basis of absolute numbers of refugees Member States have had to deal with over the previous three years. ${ }^{17}$ The decision to base the allocation of the fund on the absolute number of refugees was highly controversial, with several smaller Member States (in particular Austria) arguing that relative burdens (in relation to population size) and not just absolute burdens (in terms of total figures) should be taken into account in the ERF's allocation rules. According to the mid-term evaluation (DG Justice and Home Affairs, 2003), 51 per cent of the total ERF money dispensed was allocated to reception measures, and 28 per cent and 21 per cent respectively were allocated to integration and repatriation measures (DG Justice and Home Affairs, 2003, p. 6). The fund operates as decentralized financial instrument, with national authorities allocating ERF resources to a wide range of non-profit-making organizations (including government agencies at the national, regional or local level); education, training and research institutions; social partners and NGOs. ${ }^{18}$

The ERF's mid-term report identifies three main strategies adopted by the Member States in terms of implementing the fund's resources. One group of countries (Italy, Spain, Portugal and Greece) which had limited experience in dealing with refugees, placed special emphasis on the development of reception facilities. Member States with a longer history of asylum policy (the Netherlands, Germany, the United Kingdom, Sweden and Finland) generally relied on the fund to develop integration and voluntary repatriation projects. A third group of countries (France and Luxembourg) used the ERF primarily to increase the level of funding for activities already in operation (DG Justice and Home Affairs, 2003). On 12 February 2004, the European Commission

\footnotetext{
${ }^{16}$ Five per cent of the fund's annual budget can be used to finance innovative or transnational Community measures (studies, pilot projects, exchanges of experience, assessment of measures implemented, etc.).

${ }^{17}$ The number of applications for protection were given a 65 per cent weighting, against 35 per cent for the number of refugees accepted and displaced persons receiving temporary protection.

${ }^{18}$ Community support for the financing of projects is not to exceed 50 per cent of the total cost of each project ( 75 per cent for the Member States drawn from the cohesion fund). There are different procedures for emergency measures: financial support can cover 80 per cent of the cost of each measure for a maximum of six months. The available resources are then divided between the Member States on the basis of the number of displaced persons they receive.
} 
adopted a proposal for an extension of the ERF for the period 2005-10. The proposal was adopted in virtually unchanged form by the Council in December $2004 .{ }^{19}$ While the overall size of the fund has been roughly tripled to a proposed $€ 684$ million (pending the new budget), the main principles underlying its allocation rules have virtually stayed unchanged. According to Article 17 of the decision, each Member State shall receive a fixed amount of $€ 300,000$ from the fund's annual allocation, with a special arrangement for the new Member States which will receive $€ 500,000$ per annum for 2005, 2006 and 2007. The remainder of the available annual resources shall be broken down between the Member States as follows: 30 per cent in proportion to the absolute number of Geneva Convention refugees and persons having been granted some subsidiary protection status: 70 per cent in proportion to the absolute number of applications for protection status received over the previous three-year period. Under ERF-II, each Member State will be required to submit multi-annual plans to the Commission for prior approval. This will give the Commission a greater role in planning and pooling resources and will encourage Member States to develop longer-term strategic plans. At the same time, the Council has reduced the percentage of ERF money earmarked for Community-wide projects from the 10 per cent proposed by the Commission to 7 per cent (up from 5 per cent under ERF-I).

\section{Refugee Burden-Sharing and EU Redistributive Politics}

What does the above analysis of the establishment and working rules of the ERF tell us about the motivations behind the fund and its operational logic? Returning to the discussion at the outset, it will be asked whether the ERF can be understood in terms of the traditional redistributive logics linked to rationales of insurance, solidarity or side-payments.

First, regarding the insurance logic, it is not implausible to assume that financial burden-sharing instruments, in principle, allow states to set off today's contributions against the expectations of reduced costs in a future crisis. As the world grows smaller and more interconnected, and as an increasing number of refugees can more easily reach more places and claim protection there, a 'refugee crisis insurance' might well be a 'good buy' - perhaps even for relatively insular states (Schuck 1997, p. 249). Although a considerable percentage of the fund (70 per cent of its variable element) would respond to a sudden change in the direction of refugee flows into the EU, the ERF's insurance logic is undermined by at least two factors. Above all, its insurance capacity is undermined by the ERF's small resources compared to domestic resources that Member

${ }^{19}$ Council Decision of 2 December 2004 (2004/904/EC; OJ381/52 of 28/12/2004). 
States make available for the purpose of refugee protection. According to UK Home Office estimates, Britain spent just under $€ 30,000$ per asylum-seeker in 2002, if one includes administrative costs, legal bills, accommodation and subsistence. According to figures from the fund's mid-term review, the UK was the second largest recipient of the fund in 2002, and received just over $€ 100$ ERF money per asylum application received that year. Moreover, the ERF's insurance logic is also undermined by the fact that the risks facing the different Member States are very unevenly distributed as a result of differing structural pull factors. The risk of high future inflows will always tend to be higher for EU countries with strong historical ties with potential countries of origin or Member States with a vulnerable EU external border.

Second, the question of the fund's solidarity credentials will be addressed in three parts, focusing on its fixed element, its proportional mechanism and its overall effect. While the fixed element is likely to have played an important role in getting overall agreement on the principle of the fund (as every Member State did receive something from the fund), it should be viewed as having been ineffective regarding the fund's solidarity objective. If each Member State receives the same amount from this fixed element of the fund, no progress in terms of burden-sharing will be made. This appears to have been recognized as the decision establishing the fund prescribes a scaling down of this element over the fund's five-year period. It is often argued that, in terms of the fund's solidarity objective, the fixed element has played an important role, as it has supported Member States with less developed protection systems irrespective of the number of displaced persons they received. However, it has of course also supported Member States with well-developed asylum systems and small numbers of protection-seekers in equal measure. It hard to argue therefore that the fund's fixed element is an effective expression of Community solidarity. If the objective of the fund is to help particular Member States to develop their asylum institutions, then there must be better ways of doing this than by giving each Member State the same amount (i.e. by assessing need). The ERF decision for the $2005-10$ period starts to address this problem only by allocating a greater fixed element to the Union's new Member States. ${ }^{20}$

Regarding the fund's proportional element, it can be argued that although having performed better, the solidaristic and redistributive effect achieved here remains very much sub-optimal. Currently that part of the fund is distributed on the basis of the absolute number of displaced persons received in a Member State. This means that a particular number of protection-seekers triggers the

\footnotetext{
${ }^{20}$ In its (non-binding) opinion on the Commission ERF-II proposal, the European Parliament recognized the problematic nature of the new fund's envisaged fixed element and proposed to cut by half the fixed annual allocation to the existing Member States (EU-15) (Europe Information Service, European Report, 20 March and 21 April 2004).
} 
same amount of money under this category irrespective of the receiving country concerned. This has led to the result that countries with large absolute numbers have benefited disproportionately, while other countries with much greater relative burdens (e.g. relative to population or size of GDP) have benefited less. The underlying assumption appears to be that the same amount of effort is rquired for a particular number of protection-seekers received, no matter whether the receiving state is small or large, rich or poor, etc. This is clearly not the case, as a certain number of protection-seekers received will require greater efforts by a small/poor country than a large/rich one. In sum, while the idea of a fixed element seems to run counter to the ERF's redistributive objectives, the fund's proportional element currently compensates Member States according to the absolute numbers of protection-seekers received rather than according to the relative responsibilities that Member States are faced with which, again from a solidarity perspective, appears less than ideal (see Table 2).

Finally, is there evidence of package deals, side-payments or a quid pro quo logic? At the most general level, there appears little to suggest that the fund's overarching rationale is to increase the willingness by those countries on the

Table 2: The Redistributive Impact of the European Refugee Fund

\begin{tabular}{|c|c|c|c|}
\hline Country & $\begin{array}{c}\text { \% of ERF Contribution } \\
\text { to all MS } \\
\text { (by 2002) }\end{array}$ & $\begin{array}{c}\text { Absolute Nos of } \\
\text { Asylum Applications } \\
\text { (2000) }\end{array}$ & $\begin{array}{c}\text { No. of Asylum Applications } \\
\text { per } 1000 \text { Head of } \\
\text { Population } \\
\text { (2000-02 Average) }\end{array}$ \\
\hline Germany & $20.05 \quad(1)$ & 78,564 & 0.9 \\
\hline United Kingdom & $19.11 \quad(2)$ & 98,900 & 1.7 \\
\hline France & 11.50 & $38,747 \quad(5)$ & $0.6 \quad(11)$ \\
\hline Netherlands & $9.46 \quad(4)$ & 48,395 & 2.8 \\
\hline Sweden & $8.37 \quad(5)$ & $16,303 \quad$ (7) & 1.8 \\
\hline Italy & $8.06 \quad(6)$ & $15,564 \quad(8)$ & $0.3 \quad$ (13) \\
\hline Belgium & $5.73 \quad(7)$ & 42,691 & 4.2 \\
\hline Austria & $5.06 \quad(8)$ & 18,284 & 2.2 \\
\hline Ireland & $2.69 \quad(9)$ & 11,096 (10) & 2.9 \\
\hline Spain & $2.59(10)$ & 7,926 (11) & $0.2 \quad(14)$ \\
\hline Finland & $2.35(11)$ & $3,170 \quad(12)$ & $0.6 \quad(10)$ \\
\hline Greece & $2.35(12)$ & $3,083 \quad(13)$ & $0.3 \quad(12)$ \\
\hline Portugal & $1.77(13)$ & 224 & $0.02(15)$ \\
\hline Luxembourg & $1.12(14)$ & $628(14)$ & 1.4 \\
\hline Denmark & & 12,200 & 2.3 \\
\hline
\end{tabular}

Source: Data from D6 Justice and Home Affairs (2003) and author's own data. 
receiving end of ERF money to accept more refugees than they currently do. Given the relatively small scale of the fund (compared to national expenditure in this area), one should not expect the ERF receipts to be able to provide such incentives. Despite the substantial increase in the funding for ERF-II, the fund remains stronger on symbolism than on substance. However, the evidence presented here appears to offer at least some support for the argument that the ERF has been used as a device to overcome potential obstacles to EU policy harmonization in this area. This is supported by statements Commissioner Vitorino made when the Commission adopted its proposal for ERF-II. He said: 'What we need to do now is express Community financial solidarity in an even more meaningful way and thereby help the Member States apply the new European rules and support the definition of a second stage of harmonisation that will be more ambitious than what was agreed at Tampere'. ${ }^{21}$ In line with this argument, we would expect the allocation rules of the fund to favour those Member States which have most to lose from policy harmonization in this field. This indeed appears to have been the case. ${ }^{22}$ The countries which have most to lose from asylum policy harmonization are those which have been most active in using national restrictions in an attempt to reduce the numbers of refugees coming to their countries. Empirically, one observes that the countries which have attracted the largest absolute numbers of asylum-seekers have also tended to be those which have most extensively used restrictive national deterrence measures in recent years (Thielemann, 2004). It has been shown that countries which attract disproportionate numbers of asylum-seekers often do so as a result of structural pull factors, i.e. factors that are related to the geographic, economic or historical characteristics/legacies of a country that make their country relatively more attractive as a destination country (Thielemann, 2004). In the past, such countries have been free to use national policy restrictions (within the somewhat vague constraints of international law) in their attempt to counteract the impact of these structural pull factors. EU policy harmonization will put an end to such unilateral (counteracting) measures. The European Commission explicitly acknowledges this when stating:

The ERF is an important part of an overall policy for building a common European asylum policy. Reducing divergence between asylum systems and

\footnotetext{
${ }^{21}$ European Commission Press Release (RAPID, IP04/203 of 13 February 2004).

${ }^{22}$ Not surprisingly, the two principal beneficiaries of the ERF's current allocation rules have frequently thrown spanners in the wheels of the harmonization process in the area of asylum and immigration. The UK did so in particular by securing an opt-out from JHA provisions. Germany, although seen by some as a driver in this process, has frequently obstructed the harmonization process in this area with its reservations on issues such as 'non-state prosecution' in the negotiations on the Directive on refugee qualification. It insisted on a clause in the asylum procedure Directive that allows children over 16 years to be denied the special assistance to which other children are entitled, and more recently in the discussions surrounding the Hague Programme it insisted that each EU member will retain its veto over decisions relating to legal immigration.
} 
progressive implementation of common standards at EU level will have a cost, which will be greater for Member States with larger number of asylumseekers and refugees. (Commission, 2004, p. 7)

When analysing the allocation of ERF resources, one finds that the fund's principal beneficiaries are not only the countries which are the largest recipients in terms of the absolute numbers of refugees received, but are also the countries which have introduced some of the strictest national asylum measures. In other words, the current ERF allocation rules benefit above all those who have most to lose from EU policy harmonization. More generally, the above analysis seems to suggest that, while the decision to create an EU refugee fund can be interpreted as an act of symbolic (and partly solidaristic) EU politics, the decision on the ERF's allocation rules appears to follow a more traditional side-payment logic in which countries with the strongest bargaining chips (i.e. with the greatest credible threat to cause difficulties in related areas of EU policy-making) are the ones most influential when it comes to decisions about the distribution of EU spoils.

\section{Conclusion}

It has been argued that large numbers of refugees and their highly unequal (and often inequitable) distribution among the Member States pose considerable challenges to the EU. Member States generally acknowledge that, without co-operation on these matters, restrictive national policy responses are likely to lead to a 'race to the bottom' in terms of protection standards, risk non-compliance with international law and above all jeopardize effective protection of one of the most vulnerable groups in society. Although the EU has recognized the necessity for multilateral policy responses to address the issue of refugee responsibility- or burden-sharing, this article has highlighted some limitations of EU initiatives in this area. With physical burden-sharing measures remaining highly controversial, and likely to remain limited given many Member States' opposition to national quotas, the emphasis of EU policy development has been on the European-wide harmonization of rules and the financial compensation of Member States through the ERF. Indeed, it has been argued that these two developments have been closely linked. As a result of these linkages, the ERF's current allocation rules restrict its burden-sharing impact (already limited due to the fund's modest size), and undermine the fund's ability to encourage Member States to enhance their refugee protection efforts. As in other areas of the EU, sensitivities about net contributions to the common budget and a prevailing logic of side-payments limit the impact of EU redistributive politics. Ultimately, with the ERF, as with other EU redistributive instruments, symbolic politics and juste retour claims trump effective burden-sharing. 
Correspondence:

Eiko R. Thielemann

Department of Government

London School of Economics and Political Science

Houghton Street

London WC2A 2AE, UK

Tel: +44 (0)20 79556012 Fax: +44(0)20 78311707

email: e.thielemann@1se.ac.uk

\section{References}

Axelrod, R. (1984) The Evolution of Co-operation (New York: Basic Books).

Bloch, A., Galvin, T. and Schuster, L. (eds.) (2000) 'Changing Asylum Policies in Europe'. Special Issue of the Journal of Refugee Studies, Vol. 13. No. 1.

Boswell, C. (2003) 'Burden-Sharing in the EU: Lessons from the German and UK Experience'. Journal of Refugee Studies, Vol. 16, No. 3, pp. 316-35.

Buchanan, J. and Tullock, G. (1962) The Calculus of Consent (Ann Arbor: University of Michigan Press).

Carrubba, C.J. (1997) 'Net Financial Transfers in the European Union: Who Gets What and Why?'. Journal of Politics, Vol. 59, No. 2, pp. 469-96.

DG Justice and Home Affairs (2003) Mid-term Evaluation of the European Refugee Fund Final Report (Brussels: CEC).

Domar, E. and Musgrave, R.A. (1944)'Proportional Income Taxation and Risk-Taking'. Quarterly Journal of Economics, Vol. 58, pp. 388-422.

Commission of the European Communities (2004) 'Proposal for a Council Decision establishing the European Refugee Fund for the period 2005-2010: Extended Impact Assessment'. Commission Staff Working Paper COM(2004)102 final, Brussels, 12 February.

European Council (2000) 'Council Decision creating a European Refugee Fund'. Document SN 200/99.

Friman, H.R. (1993) 'Side-payments versus Security Cards: Domestic Bargaining Tactics in International Economic Negotiations'. International Organization, Vol. 47, No. 3, pp. 387-410.

Guild, E. and Harlow, C. (2001) Implementing Amsterdam: Immigration and Asylum Rights in EC Law (Oxford: Hart).

Laffan, B. (2000) 'The Big Budgetary Bargains: From Negotiation to Authority'. Journal of European Public Policy, Vol. 7, No. 5, pp. 725-43.

Lubbers, R. (2004) 'EU Should Share Aslum Respsonsibilities, not Shift them'. UNHCR News, 5 November.

Marks, G. (1993) 'Structural Policy and Multilevel Governance in the EC'. In Cafruny, W.A. and Rosenthal, G.G. (eds) The State of the European Union: The Maastricht Debate and Beyond (Harlow: Longman).

Mason, A. (2000) Community, Solidarity, and Belonging: Levels of Community and their Normative Significance (Cambridge: Cambridge University Press). 
Milner, H. (1992) 'International Theories of Co-operation among Nations'. World Politics, No. 44, pp. 466-96.

Moravcsik, A. (1991) 'Negotiating the Single European Act: National Interests and Conventional Statecraft in the European Community'. International Organization, Vol. 45, No. 1, pp. 19-56.

Neumayer, E. (2005) 'Asylum Recognition Rates in Western Europe -Their Determinants, Variation and Lack of Convergence'. Journal of Conflict Resolution (forthcoming).

Noll, G. (1997) 'Prisoner's Dilemma in Fortress Europe: On the Prospects for Equitable Burden-Sharing in the European Union'. German Yearbook of International Law, Vol. 40, pp. 405-37.

Noll, G. (2000) Negotiating Asylum (The Hague: Martinus Nijhoff).

Putnam, R. and Bayne, N. (1987) Hanging Together (Cambridge, MA: Harvard University Press).

Pollack, M. (1995) Regional Actors in an Intergovernmental Play: The Making and Implementation of EC Structural Policy (Harlow: Longman), pp. 361-90.

Rawls J. (1971) A Theory of Justice (Oxford: Oxford University Press).

Shackleton, M. (1993) 'The Delors II Budget Package'. In Nugent, N. (ed.) The European Community 1992. Annual Review of Activities, Journal of Common Market Studies, Vol. 31, pp. 11-25.

Schuck, P. (1997). 'Refugee Burden-Sharing: A Modest Proposal'. Yale Journal of International Law. Vol. 22, pp. 243-97.

Thielemann, E. (2002) 'The Price of Europeanisation: Why European Regional Policy Initiatives are a Mixed Blessing'. Regional and Federal Studies, Vol.12, No.1, pp. 43-65.

Thielemann, E. (ed.) (2003) 'European Burden-Sharing and Forced Migration'. Special Issue of the Journal of Refugee Studies, Vol. 16, No.3.

Thielemann E. (2004) 'Why European Policy Harmonization Undermines Refugee Burden-Sharing'. European Journal of Migration and Law, Vol. 6, No. 1, pp. 43-61.

Thielemann, E. (2005) 'The Effectiveness of Asylum Policy in Controlling Unwanted Migration'. In Parsons C. and Smeeding T. (eds) Immigration and the Transformation of Europe (Cambridge: Cambridge University Press).

UNHCR (1995) 'Collection of International Instruments and Other Legal Texts Concerning Refugees and Displaced Persons'. Volume II, Regional Instruments, UNHCR, Geneva 1995 (Geneva: UNHCR).

Wallace, H. (1977) 'The Establishment of the Regional Development Fund: Common Policy or Pork Barrel?'. In Wallace, H., Wallace, W. and Webb, C. (eds) Policy Making in the European Communities (London: Wiley).

Wallace, H. (1983) 'Distributional Politics: Dividing up the Community Cake'. In Wallace, H., Wallace, W. and Webb, C. (eds) Policy Making in the European Community (London: Wiley).

Young, O. (1989) International Co-operation (Ithaca, NY: Cornell University Press). 